\title{
Opening up the Black Box of Group Decision-Making on Solar Energy: The Case of Strata Buildings in Amsterdam, the Netherlands
}

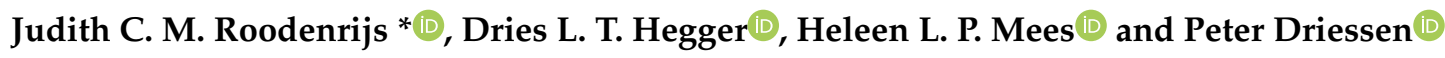 \\ Copernicus Institute of Sustainable Development, Faculty of Geosciences, Utrecht University, 3584 CB Utrecht, \\ The Netherlands; d.l.t.hegger@uu.nl (D.L.T.H.); h.l.p.mees@uu.nl (H.L.P.M.); p.driessen@uu.nl (P.D.) \\ * Correspondence: j.c.m.roodenrijs@uu.nl
}

Received: 27 January 2020; Accepted: 5 March 2020; Published: 9 March 2020

check for updates

\begin{abstract}
The adoption of solar energy is lagging behind in urban areas worldwide. Although the literature on energy transition is abundant, it has been focused mostly at the systems level. Few studies have addressed on-the-ground implementation. This paper examines a specific but prominent example of such on-the-ground practice: decision-making processes in strata buildings whose owners are organized in a (home) owners' association. These buildings constitute a significant proportion of the housing stock in European cities, and hence their role in energy transition cannot be underestimated. In strata buildings, homeowners have to reach an agreement before renewable energy measures can be implemented. These related group decision-making processes are still a black box, however. We constructed a tentative framework based on a review of group decision-making and applied literature, which we validated and refined using a survey and in-depth interviews with (home) owners' associations in Amsterdam, the Netherlands. Our study aimed to explore what the stimuli and barriers for the adoption of renewable energy measures in group settings are. Our empirical findings suggest that leadership and information processing are key factors that explain the outcomes of group decision-making processes. Whereas many are convinced that energy transitions are technically possible, their day-to-day implementation has proven to be complicated. For energy transitions to succeed, the recognition of key factors that explain the outcomes of group decision-making needs to be taken into account.
\end{abstract}

Keywords: (home) owners' association; energy transition; solar energy; group decision-making; strata buildings

\section{Introduction}

European countries have decided to set legally binding targets for renewable energy [1]. Energy consumption is high in urban areas in Europe, since 75\% of Europeans live there. Therefore, several policies and initiatives have been put in place to promote sustainable energy measures in cities [2]. A substantial proportion of the European population lives in strata buildings. In France, $43 \%$ of the population lives in strata complexes. Renting or buying an apartment is usual in Germany [3]. In Sweden, apartment ownership is also common practice [4]. In order to realize a renewable energy transition, it is of pivotal importance that strata complexes adopt sustainable energy measures. In Amsterdam in the Netherlands, $53 \%$ of the building stock is comprised of strata complexes in which owners are organized in a (home) owners' association [5]. Collective ownership of the building makes the adoption of sustainable energy measures a more complex decision-making process, not least because for most decisions, a majority of votes is needed.

There is an extensive body of literature about energy transitions at a systems level [6-9]. However, little research has been done on the detailed on-the-ground implementation of energy transitions. 
There is a lot of literature about the motives of individuals and households in adopting sustainable energy measures (e.g., Reference [10]), but this does not seem to be applicable to most of the housing stock in cities. The authors of Reference [10] implicitly confirmed this: they studied decisions to invest in major energy efficiency measures in buildings with private homeowners, using the theory of planned behavior as a starting point. That theory, however, focuses on the behavior of an individual. Respondents living in a multifamily building-i.e., those who are part of a group decision-making process-were excluded from the study [10]. For private homeowners, there is a clear link between energy savings and individual behavior. Strata buildings and the way they are organized, however, make it difficult for homeowners in these buildings to discern the link between individual behavior and sustainable energy measures [11]. This leads to there being little incentive for an individual to exhibit energy-efficient behavior. Little is known about the reasons for adopting renewable energy measures in strata buildings. References [11,12] have acknowledged the complexity of decision-making in (home) owners' associations and have recognized the need for knowledge production in this field.

Although nomenclature and legal contexts differ per country, the core purpose of (home) owners' associations (also referred to as housing cooperatives) is similar: owners must collectively maintain common property. In the Netherlands, a (home) owners' association consists of two entities: a board and a general meeting of owners. The board consists of one or several owners and is responsible for the finances and makes sure communal interest prevails. The general meeting of owners is the highest entity of the (home) owners' association, where regular decisions are based on majority voting. A decision on adopting solar energy, however, is an irregular decision and therefore requires a qualified majority ( $2 / 3$ or $3 / 4)$, which makes it more complicated to achieve a decision in favor of the measure. A strata manager has no legal power within the (home) owners' association, but is often hired by the (home) owners' association for administrative as well as technical management tasks.

Renewable energy measures can include both energy-saving and energy-generation measures. This article focuses on renewable energy-generation measures-solar energy in particular. One reason for this is that a recent study found that urban areas are not adopting solar panels at the same pace as rural areas [13]. In urban areas, the population density is higher than in rural areas, which exerts pressure on the available public space and leaves fewer options for where to place solar photovoltaic (PV) systems. Rooftops are a favored option, but if the building is collectively owned, a group decision-making process is needed. This might account for the limited application of solar panels in urban environments. At the same time, this highlights that solar PVs still have a large unrealized potential in the context of strata buildings [14]. This was confirmed by Reference [15], where it was argued that the installation of PV systems on large rooftops is of pivotal importance in realizing the energy transition in Amsterdam.

This paper aims to contribute to insights and scholarly literature on the transition to renewable energy in the urban environment. We empirically studied decision-making on the implementation of solar energy by (home) owners' associations in Amsterdam. We aimed to explore what the stimuli and barriers for the adoption of renewable energy measures in (home) owners' associations are. If we are to find ways to further stimulate energy transitions in urban areas, the collective decision-making process needs to be better understood.

The geographical focus of this research was Amsterdam, the Netherlands. In comparison to other European countries, the Netherlands is lagging behind in achieving its renewable energy generation goal [16]: in 2018, 7.4\% of the total energy demand came from renewable sources, and $0.6 \%$ of the total energy demand was produced by solar panels [17]. At the same time, strata buildings constitute a significant proportion of the housing stock. While exact numbers are unknown, the number of (home) owners' associations in the Netherlands is approximately 100,000 [18]. Amsterdam is the capital of the Netherlands: it has a high building density and many strata complexes. Amsterdam has approximately 22,000 (home) owners' associations, which is high in comparison to other cities in the Netherlands [18]. This makes Amsterdam a relevant case. 
This paper is structured as follows. Section 2 derives the factors influencing group decision-making from the psychology literature and complements this with applied literature on (home) owners' associations that make decisions on renewable energy measures. This results in a tentative explanatory framework. Section 3 discusses our research methods. An empirical confrontation of the framework with the actual situation in Amsterdam follows in Section 4. This leads to conclusions and policy recommendations in Section 5.

\section{Factors Influencing Group Decision-Making: A Literature Review}

\subsection{Procedure for Developing a Tentative Framework}

The literature does not provide a clear-cut answer to the question of how to explain decision-making in (home) owners' associations. On a more general level, to the best of our knowledge, there is no framework available on group decision-making that is directly applicable to the specific context of strata buildings. The most applicable, for us, is a literature review by Kerr and Tindale [19] on more general explanatory factors for group performance and decision-making, which we decided to use as a starting point. We further developed our framework by deriving indicators for factors affecting group decision-making from applied literature. In methodological terms, we conducted a combination of theory-oriented and practice-oriented research, where the theoretical part included the development of a tentative literature-inspired framework that was further specified through initial, explorative, and empirical confrontation.

Six categories of explanatory factors were identified in the literature [19]: groupthink, a shared mental model, cognitive centrality, procedures, sharing or combining cognitions, and combined preferences. We considered five to be applicable to (home) owners' associations. We left out the factor "combined preferences", since this factor was described in situations in which there was little or no discussion among individuals (since members of a (home)owners' association come together in a meeting, we assumed there is discussion among individuals). In addition, we wanted to go beyond an individual preference perspective. We decided to split up the factor "combining or sharing cognitions" [19] into two factors: information sharing and information processing. We understand the concept of cognition as the ability to take up and process information. "Cognition" thus refers to a normative evaluation of information, but this is preceded by information sharing itself (whether, how, and how often). In other words, one cannot evaluate information if there is no information. The two factors may thus be interrelated, but the same holds for other factors in the framework.

We decided to complement this framework with leadership: the authors of Reference [19] did not discuss this factor in detail, but they mentioned it as important in small-group decision-making settings.

Since we aimed to explore the factors influencing the solar energy decision-making process in (home)owners' associations, the dependent variable in our research was the decision outcome of the process. This was a binary variable: (home)owners' associations would reach either a positive or a negative decision about installing solar panels.

The dependent variable, the outcome of the process, was considered negative if the following were true:

1. The (home)owners' association did not manage to make a decision at the meeting (a discussion took place, but there was no official voting);

2. The decision was not included in the annual meeting agenda (the initiators decided not to submit it or failed to prepare a proposal); or

3. The majority did not vote for solar energy.

We henceforth refer to these (home) owners' associations as nonadopters. If the (home) owners' association decided in favor of installing solar panels on the roof, the outcome was considered positive. We henceforth refer to these (home) owners' associations as adopters. 
The factors described above are shown on the left side of Figure 1. Each factor will be further explained in subsequent sections and complemented with indicators derived from applied literature. The indicators are shown in the middle column of Figure 1.

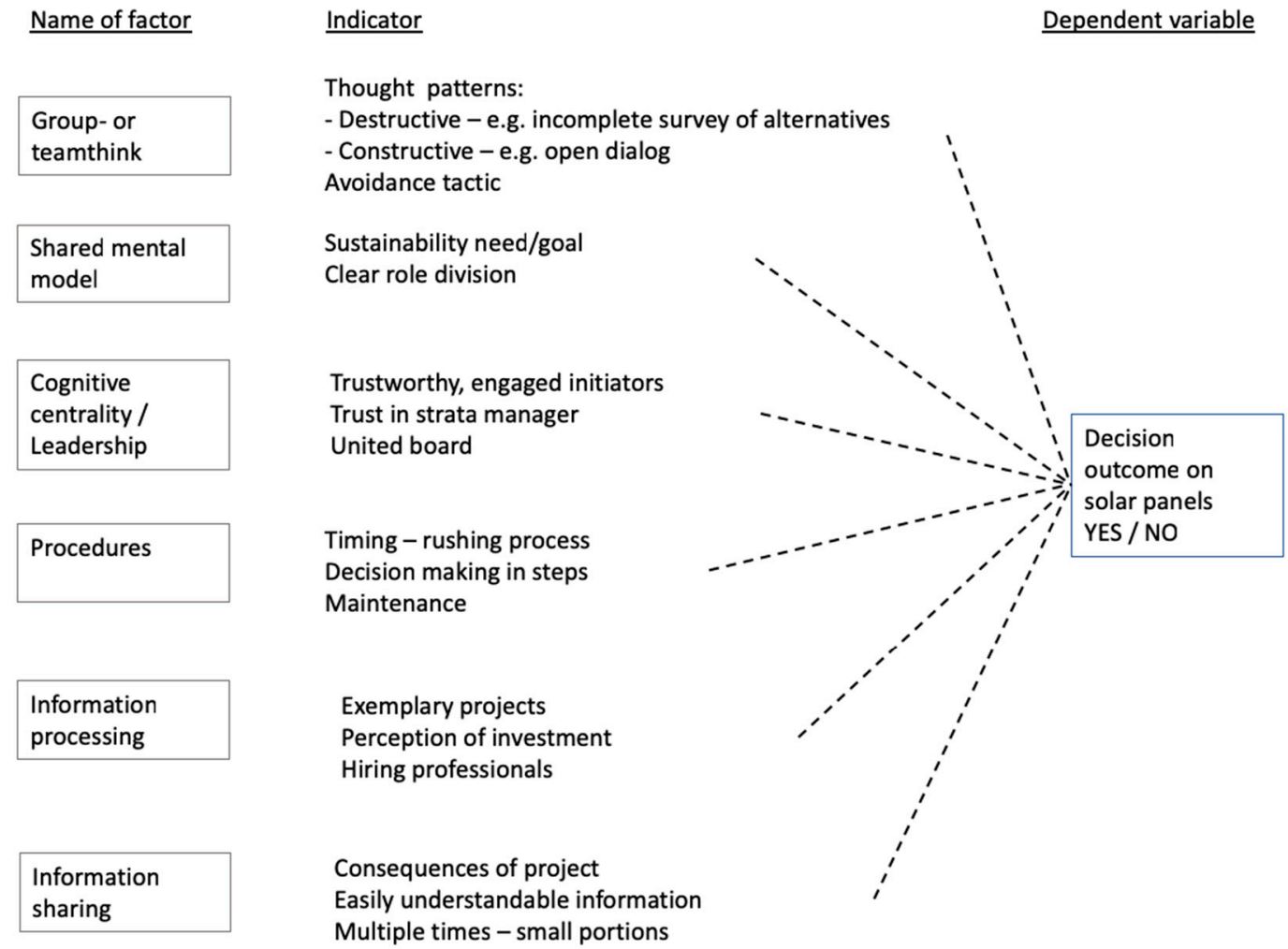

Figure 1. Tentative framework after the literature review.

\subsection{Groupthink}

One explanatory factor [19] is "groupthink". Groupthink refers to the idea that within a group, the desire for harmony (the "agreement of ideas, feelings, or actions" [20]) or cohesiveness (wanting to belong to a group, working well together) leads to groupthink, which may lead to defective decision-making [21,22]. Groupthink is more likely to occur in self-managing groups [23]. The concept has been widely discussed in the literature and has been subjected to criticism [24] and revisions [25]. At its core, groupthink entails destructive thought patterns, including an incomplete survey of alternatives/objectives, a failure to examine the risks of the preferred choice, a failure to reappraise initially rejected alternatives, a poor search for information, selective bias in processing the information at hand, and failure to work out contingency plans. However, Reference [26] argued that constructive thought patterns-positive groupthink-may also occur. This includes the encouragement of divergent views, the open expression of concerns, an awareness of limitations, the recognition of members, and the discussion of collective doubts: this can lead to an outcome based on effective decision-making. This is in line with Reference [19], who argued that groupthink can lead to both good and poor decision outcomes. The authors contended that the main contribution of the theory is that constructs that are typically seen as positive aspects of a group (e.g., the abovementioned desire for harmony or cohesiveness) do not automatically lead to improved group outcomes [27]. On top of this, Reference [25] argued that groupthink may occur during one decision-making situation but not during another. In other words, the phenomenon is context- and subject-specific. It does not automatically recur in the same group with different topics. Finally, it is also possible for groups to use discussion to avoid making a decision: Reference [28] called this is an avoidance tactic. This factor seems relevant for decision-making in (home) owners' associations, although there is only one indication of it in the 
applied literature: Reference [29] mentioned that it is important that a dialogue with residents take place in order for them to feel heard or taken seriously by the board.

\subsection{Shared Mental Model/Task Representation}

According to Reference [19], mental models (sets of ideas and values a person has about how things work or should work in reality) are often related to group decision-making. Teams in which persons have shared mental models have been found to achieve greater consensus [30]. In addition, "as long as a given individual's preference is plausible within the shared representation, the group members may find it acceptable without thorough debate" [19] (p. 639). According to Reference [31], decision alternatives that fit within the shared mental model or are supported by it are easier to defend and are thus more likely to be chosen by the group. With regard to shared task representation, groups function better when they share the same ideas about the role division of various group members (Reference [32] in Reference [19]). Applied to the context of (home) owners' associations, this means that a shared mental model of sustainability, or renewable energy in particular, could stimulate adoption. The applied literature confirms this. For instance, Reference [29] mentioned that it is important for residents to agree that there is a need for sustainable energy measures; moreover, residents must understand the importance and need for the project. In line with this, Reference [14] mentioned that it can be helpful for residents to discuss ambitions or goals with regard to sustainable energy performance.

\subsection{Cognitive Centrality and Leadership}

Cognitive centrality means that one person's opinion can be more influential than the opinion of others (cognitive peripheral group members). Reference [19] explained that persons perceived as having expertise, competence, or more information can influence the group decision. Groups are more likely to opt for this person's view. Reference [19] argued the need for more research on cognitive centrality in order to clearly understand it in the context of group decision-making. Since leaders can influence group decisions, we linked this factor with some basic thoughts on leadership: leaders can be useful in achieving goals or may facilitate change [33]. In addition, strong, directive leaders can enhance performance [34]. Sometimes, a group leader can aid in information sharing [35].

The applied literature confirms the relevance of cognitive centrality and leadership. Reference [29] noted that in order to succeed, processes must be organized and initiated by trustworthy and engaged individuals. These individuals are presumably board members, consultants/professionals, or engaged residents. Reference [11] also noted the importance of trusting strata managers. According to Reference [29], it is important that the board is united or expresses a common opinion to the members of the cooperative. This is in line with Reference [11], who argued that one or several owners need to take a leadership role and that it takes a dedicated group of people working together with one mission.

\subsection{Procedures}

How a decision-making procedure is set up can influence the outcome. Reference [19] described three influential elements: timing, breaking the topic into several parts, and forming subgroups. As can be derived from Reference [36], trying to reach a consensus too early in the process increases the likelihood of no decision being taken. In addition, breaking up a decision into component parts can change the types of decisions groups will reach [37]. Finally, minority positions within a group are more likely to be chosen if the group is broken up into subgroups and these subgroups are allowed to make decisions before the subgroup decisions are combined.

We did find some confirmation of the above in the applied literature. According to Reference [38], the decision-making process in a (home) owners' association can take one to three years. The authors showed that processes that are rushed are unsuccessful and suggested not putting a decision to the vote until members have been adequately informed. The latter can be achieved by sharing information in the process and providing it in small portions both in writing and orally throughout the process. 
If information comes too late, people may have negative feelings about the project [29]. Furthermore, in relation to breaking the decision into component parts, Reference [14] argued that residents should be involved in an early phase, e.g., first discussing the goals for sustainable energy measures in a general meeting before voting on the details.

Finally, with regard to procedures, we found a factor that is specifically applicable to (home) owners' associations. In the Netherlands, each (home) owners' association is legally obliged to set aside $0.5 \%$ of the total sum needed for reconstruction or maintenance of the building annually. It is quite common for (home) owners' associations to draw up a maintenance plan for several years that indicates what needs to be done in the near future. Both References [14] and [11] have suggested combining sustainable energy measures with planned maintenance of the building, since this may help achieve a positive outcome.

\subsection{Information Sharing and Information Processing}

Reference [39] argued that groups are less than optimal users of information and often ignore information that is not widely shared among the members. In addition, shared information is more likely to be discussed [39], at the expense of unshared information. However, the longer the discussion lasts, the more likely it will be that the information is shared. Both information sharing and information processing were mentioned by the authors, and the concepts seem to influence each other. This was confirmed by Reference [40]: in a situation where most members already share the same preference, this could lead to reduced information exchange and early consensus, including in the case of majority decisions. With regard to information sharing, people prefer to both receive and present information that others already know [41]. With regard to information processing, group members do not like to change their initial preferences once these have formed [42]. In that sense, additional information that is shared would not necessarily help. What can help with information sharing is having at least one group member who is an advocate for the alternative contained in unshared information [42].

The applied literature provides indications of information sharing and information processing influencing a decision. We therefore treated these two separately in our tentative framework. According to Reference [29], residents should receive detailed information about the consequences of renewable energy measures on their strata fees, as then they will be more likely to vote for the sustainable energy measures. This is in line with Reference [14], which argued that communication about what a sustainable energy measure means in terms of energy savings and investment is important for a positive decision. Reference [14] also mentioned the potential importance of less quantifiable factors (e.g., convenience), but thus far not much has been written about this in Energy Performance Contracting (EPC) literature, and we considered reasons of convenience to be not that relevant in the case of solar energy. Another thing important for a positive outcome is that information is easy to understand, e.g., presented in pictures, illustrations, and without jargon [29]. Reference [14] mentioned aesthetics being more important for residents than energy savings. According to Reference [29], what gets people engaged is visual and practical changes, not numbers and costs. If information is given in small portions over a longer time span, the groundwork for decision-making is laid [29].

Reference [29] noted that exemplary projects positively influence people's preferences. In addition, individuals tend to evaluate whether they consider an investment wise, but this varies depending on a person's financial situation and whether he/she plans to move. Reference [14] mentioned that it is people who decide which measures should or should not be initiated, which implies that this takes more than a presentation of factual information and that subjectivity plays a role.

\section{Methods}

Our study was a qualitative study. Qualitative research is characterized by small sample sizes. In order to reach valid research results, it is important to use a triangulation of data collection methods [43]. In this research, we tried to achieve this by doing desk research, a survey, and semistructured interviews. We emphasize that our study was an explorative study and by no means a 
representative statistical reflection of the population. We do, however, think that a more quantitative approach with a larger sample size would be an interesting subject for further research.

In our selection of (home) owners' associations, we selected cases that were as similar as possible on all features besides the factors contained in the framework to increase comparability. According to Reference [29], several factors at the societal level influence decision-making in (home) owners' associations: owner structure, a lack of knowledge among professional actors/decision-makers, regulations, and incentives. We tried to neutralize these societal factors in our study, and therefore focused solely on (home) owners' associations with the following characteristics:

(a) A similar owner structure (at least $50 \%$ privately owned);

(b) Located in the municipality of Amsterdam (and thus subject to the same local regulations and incentives);

(c) Started the process of deciding on adopting solar energy in the same time frame (between July 2016 and May 2017) (all of the (home)owners' associations were interviewed in 2018/2019, which meant all of them had an annual meeting in which the project could be decided upon); and

(d) Made use of professional advice (this meant that costs and benefits were calculated; the technical, organizational, and legal context was explained; and residents' questions were answered).

We considered Amsterdam, the Netherlands, to be a particularly interesting subject of study, since the country is lagging behind year after year in terms of its renewable energy share compared to other European countries [16].

We telephoned 50 (home) owners' associations and invited them to participate in our research: 9 were adopters and 41 were nonadopters. We succeeded in contacting 33 (home) owners' associations and surveyed 27 of them (all nonadopters) and interviewed the other 6 cooperatives in depth ( 3 adopters, 3 nonadopters). Our contact person in the (home) owners' association was always the person who had proposed installing solar panels.

First, we explored our tentative framework in general through our survey. We asked the initiator what they thought had caused the negative outcome and asked them to briefly elaborate on the details. We approached the respondents with open questions, meaning that we did not provide any indicator suggestions. If the respondent mentioned an indicator, we added " 1 " in that respective column. When the survey was finished, we added up the similar answers. "Perception of investment" was mentioned 13 times by survey respondents, and it was considered to be a barrier (indicated by "-").

The survey was followed by a more in-depth exploration among (home) owners' associations. We interviewed three adopters and three nonadopters. This made it possible to allow for differences in the independent variables. Semistructured interview questions were used for the in-depth interviews, in which the questions were related to the factors of our tentative framework. This allowed for a more in-depth exploration of all the factors of our tentative framework and made it possible to address factors not mentioned spontaneously by the interviewees. We used the results of both the survey and in-depth interviews to validate and refine the tentative framework.

The survey was conducted over the phone, and answers were transcribed and summarized. They were categorized by the lead author and entered in a table if they tallied with an indicator in the framework. Answers not tallying with an indicator in the framework were grouped (if possible) and given a "new" indicator.

The in-depth interviews were conducted by phone or in person. The questions were linked to indicators in the framework. We transcribed the interviews, and then parts of the transcript were categorized in terms of the interview questions. We included an answer in Table 1 if it was spontaneously mentioned in reaction to the open question, if it was implicitly mentioned multiple times, or if it was mentioned as "very important or influential on the outcome". 
Table 1. Revised tentative framework after empirical confrontation.

\begin{tabular}{|c|c|c|c|c|c|}
\hline $\begin{array}{l}\text { Factor (\# of Responses } \\
\text { Related to the Factor) }\end{array}$ & $\begin{array}{c}\text { Indicator } \\
\text { (Stimulus Indicated by }+ \text { and } \\
\text { Barrier Indicated by -) }\end{array}$ & $\begin{array}{c}\text { Survey } \\
\text { Nonadopters } \\
n=27\end{array}$ & $\begin{array}{l}\text { In-Depth Interview } \\
\text { Nonadopters } \\
n=3\end{array}$ & $\begin{array}{l}\text { In-Depth Interview } \\
\text { Adopters } \\
n=3\end{array}$ & Brief Explanation \\
\hline \multirow[t]{2}{*}{ Group- or team-think (7) } & $\begin{array}{l}\text { Destructive }(-) \text { or constructive } \\
(+) \text { thought patterns }\end{array}$ & $2(-)$ & $1(-)$ & $1(+)$ & $\begin{array}{l}\text { Destructive (-): group relations are not that good; people do not } \\
\text { dare to vote against home extensions; too much negative } \\
\text { energy due to other agenda items } \\
\text { Constructive (+): people dare to give their own opinion; } \\
\text { questions were discussed in an open and honest manner }\end{array}$ \\
\hline & Avoidance tactic (-) & $2(-)$ & $1(-)$ & & $\begin{array}{l}\text { People tend to be positive but then vote against; solar panels } \\
\text { will be reconsidered after the roof has been insulated; further } \\
\text { research is always the outcome }\end{array}$ \\
\hline Shared mental model (4) & $\begin{array}{l}\text { Sustainability need or goal }(+) \\
\text { or lack thereof }(-)\end{array}$ & $1(-)$ & & $3(+)$ & $\begin{array}{l}\text { Sustainability need or goal (+): everyone is open to the idea; } \\
\text { money reserved for investment in solar energy; goal to use only } \\
\text { renewable energy } \\
\text { No sustainability goal (-): little interest in solar energy }\end{array}$ \\
\hline \multirow{3}{*}{ Leadership (13) } & $\begin{array}{c}\text { Engaged initiator }(+) \text { or lack } \\
\text { thereof }(-)\end{array}$ & $6(-)$ & & $1(+)$ & $\begin{array}{l}\text { Lack of engaged initiator (-): initiator decided to stop; initiator } \\
\text { no longer on the board; initiator moved or plans to move; no } \\
\text { one willing to lead the process; no concrete plan has been } \\
\text { created by the board } \\
\text { Engaged initiator (+): one group or leader takes up the subject } \\
\text { important there is one leader; a lot of time is invested in leading } \\
\text { the project }\end{array}$ \\
\hline & Position of board (- or + ) & $2(-)$ & $1(-)$ & $1(+)$ & $\begin{array}{l}\text { Barrier (-): board did not take up the subject; understaffed } \\
\text { board; board did not support the project; we are trying to create } \\
\text { a new board; one board member was interested, the other not } \\
\text { Stimulus (+): initiator collaborated well with the board; the } \\
\text { board was united and positive; communication with the board } \\
\text { was good }\end{array}$ \\
\hline & Trust in initiator $(+)$ & & & $2(+)$ & $\begin{array}{l}\text { Residents trusted initiator and appreciated honesty; room for } \\
\text { questions several times in process led to trust in initiators; } \\
\text { board is trusted by members }\end{array}$ \\
\hline Procedures (6) & Maintenance on roof $(-$ or +$)$ & $4(-)$ & $1(-)$ & $1(+)$ & $\begin{array}{l}\text { Barrier (-): roofing needs to be renewed in 1-3 years; insulate } \\
\text { roof first; vote after maintenance work on the roof; } \\
\text { postponement of decision due to hassle of maintenance on roof } \\
\text { Stimulus (+): roofing recently done (1-2 years) }\end{array}$ \\
\hline
\end{tabular}


Table 1. Cont.

\begin{tabular}{|c|c|c|c|c|c|}
\hline $\begin{array}{l}\text { Factor (\# of Responses } \\
\text { Related to the Factor) }\end{array}$ & $\begin{array}{c}\text { Indicator } \\
\text { (Stimulus Indicated by }+ \text { and } \\
\text { Barrier Indicated by -) }\end{array}$ & $\begin{array}{c}\text { Survey } \\
\text { Nonadopters } \\
n=27\end{array}$ & $\begin{array}{c}\text { In-Depth Interview } \\
\text { Nonadopters } \\
n=3\end{array}$ & $\begin{array}{c}\text { In-Depth Interview } \\
\text { Adopters } \\
n=3\end{array}$ & Brief Explanation \\
\hline \multirow[t]{3}{*}{$\begin{array}{l}\text { Information } \\
\text { processing (22) }\end{array}$} & $\begin{array}{c}\text { Perception of investment (- or } \\
+ \text { ) }\end{array}$ & $13(-)$ & $1(-)$ & $2(+)$ & $\begin{array}{l}\text { Barrier (-): payback time considered to be too long or a } \\
\text { disappointment; higher savings expected; business case } \\
\text { considered not good; subsidies are a prerequisite; too } \\
\text { expensive; investment considered too high; technical } \\
\text { committee skeptical of business case; neighboring complex had } \\
\text { a more positive payback time; relatively high investment } \\
\text { compared to energy-saving measures; business case insecure } \\
\text { because of existing regulations; high costs; little willingness to } \\
\text { make a long-term investment } \\
\text { Stimulus (+): interest rate higher than bank's; the } \\
\text { (home)owners' association had an equity surplus }\end{array}$ \\
\hline & Assistance of professionals (+) & & & $3(+)$ & $\begin{array}{l}\text { Independent advice (on technical possibilities); sufficient } \\
\text { objective information to inform everyone }\end{array}$ \\
\hline & Conflicts of interest (-) & $4(-)$ & $1(-)$ & & $\begin{array}{l}\text { Competition with rooftop terraces; competition with potential } \\
\text { rebuilding of the top floor apartments; many other things } \\
\text { needed attention (rebuilding, maintenance, legal issues); solar } \\
\text { panels are considered important but preferably not placed on } \\
\text { our own rooftop (Not in My Back Yard - NIMBY); solar panels } \\
\text { are not a priority }\end{array}$ \\
\hline \multirow[t]{2}{*}{ Information sharing (12) } & $\begin{array}{l}\text { Financial consequences of } \\
\text { project }(- \text { or }+)\end{array}$ & $2(-)$ & $2(-)$ & $1(+)$ & $\begin{array}{l}\text { Barrier (-): unclear who has to pay for what; unclear } \\
\text { consequences for strata fees; consequences for strata fees not } \\
\text { calculated } \\
\text { Stimulus (+): consequences for strata fees were clear; no } \\
\text { consequences for strata fees due to equity in (home)owners' } \\
\text { association }\end{array}$ \\
\hline & Easy to understand info $(+)$ & $5(-)$ & $1(-)$ & $1(+)$ & $\begin{array}{l}\text { Barrier (-): project was considered complex by initiator(s); } \\
\text { project is technically complex; difficult to choose between } \\
\text { technical options; technical possibilities were considered } \\
\text { complex } \\
\text { Stimulus (+): presentation of structured, clear information due } \\
\text { to professional help }\end{array}$ \\
\hline
\end{tabular}


In Table 1, factors that had a positive influence are presented as stimuli (indicated by a plus sign $(+)$ ), and factors that had a negative influence are indicated as barriers (indicated by a minus sign (-)). The numbers in the column refer to the number of times this indicator was mentioned.

\section{Results}

In this section, we present our revised tentative framework after empirical confrontation, followed by a textual explanation of the results from our survey and in-depth interviews (for each factor).

\subsection{Groupthink}

Individuals strive for harmony within a group, which may lead to groupthink. Groupthink can affect a process positively (constructive thought patterns, e.g., open dialogue) or negatively (destructive thought patterns, e.g., an incomplete survey of alternatives, avoidance tactics), thereby possibly influencing the outcome.

Although the answers differed in nature, the responses from two survey respondents indicated that destructive thought patterns influenced nonadoption. One person argued that people do not dare to vote against something (in this case, the home extensions of people living on the top floor), which clearly indicates that within this (home) owners' association, there was a desire for harmony in the group. Another respondent argued that group relations were not that good (but this could be considered a prerequisite for an open dialogue). The answers from two survey respondents indicated that avoidance tactics negatively influenced the outcome.

One respondent from the in-depth interviews argued that in general, the majority seemed to vote by going along with the others, which suggests that there is indeed a desire for group harmony that influences the outcome. However, adopters and most nonadopters alike contended that questions were discussed in an open manner and that it was possible for people to state their opinion and to ask questions. One nonadopter was an exception: the negative atmosphere in the annual meeting influenced the setting in which the project was discussed. The answer from one nonadopter indicated that avoidance tactics took place and negatively influenced the outcome: further research was the outcome again and again.

There are a few indications that groupthink or team-think influenced the outcome. Our findings seem to be in line with findings in the literature in the sense that there was an indication (though it was not very strong) that constructive thought patterns tended to result in adoption whereas negative thought patterns did not.

\subsection{Shared Mental Model}

If individuals have the same ideas about role division within a (home) owners' association or if they share the need for sustainability or share a goal, one can argue that their mental models are similar. This may positively influence the outcome. If the mental model is not shared, the converse applies.

One survey respondent (a nonadopter) spontaneously mentioned there was little interest in solar energy, which implies the group did not experience a need to adopt sustainability measures.

Regardless of the decision taken, the in-depth interviews showed that role division was considered to be clear, and most respondents contended that residents' attitudes toward solar panels were positive: only one nonadopter contended that most people were not interested. When asked whether energy performance goals had been set, none of the respondents responded in the affirmative. However, all adopters provided indications that such goals had been set: one adopter mentioned that the (home) owners' association agreed that it should use only renewable energy, another adopter mentioned that it had been decided to reserve money for an investment in solar energy in a previous meeting, and yet another adopter implied that the (home)owners' association had decided to generate solar energy.

An interesting difference that emerged from the in-depth interviews is that in the annual meetings of the adopters, there was hardly any discussion. One adopter mentioned that people agreed quickly, 
and the two other adopters mentioned that it was a formality in the annual meeting. Two nonadopters said that there was only a discussion (and no vote).

Our findings are in line with those from the literature as incorporated in the framework: little debate took place in the annual meetings of the adopting (home) owners' associations. All of the (home) owners' association interviewees mentioned there was a positive attitude toward solar energy: from this, it can be argued that in all cases there was a shared idea of the need for, or importance of, renewable energy measures. However, the adopters did provide indications of energy goals being set, whereas the nonadopters did not. Although the interviews revealed that a clear role division was present in all cases (both adopters and nonadopters), this was never spontaneously mentioned as an indicator in the survey (all non-adopters).

\subsection{Leadership Results}

Our literature study showed that leadership may refer to trustworthy and engaged initiators, trust in the strata manager, and a united board. All of these may positively influence the outcome.

Our survey confirmed the importance of leadership: six nonadopters provided several indications that there was a lack of engaged leadership (initiators had moved or planned to move, after which the process stopped; initiators decided to quit; or no one was willing to lead the process). Two nonadopters mentioned the board as being negative toward the project, or as being in transition.

Independently of the outcome, our in-depth interview results showed that the lead was taken by one or more initiators. Two adopters explicitly mentioned this as being important for the outcome. All respondents mentioned that they were perceived as trustworthy or taken seriously by others, but two adopters mentioned trust spontaneously (and several times), i.e., trust in the board or trust because there was room to ask questions. Two adopters also mentioned that people appreciated us taking the effort to do research upon this topic.

The initiating group was united, regardless of the outcome, except in the case of one nonadopter: "I was the only one interested or enthusiastic about it [adopting solar energy]. The others were not."

It is interesting that the adopters mentioned that the board was functioning well, the communication of the committee with the board was going well, and/or the board was united and in line with the ideas of the initiating committee. The opposite seemed to be true for the nonadopters: here the board was understaffed, in transition, or not united. This shows that the board has a crucial role in the process. Finally, all respondents who were interviewed in-depth mentioned that much time or effort had been put into the project, showing that they were all engaged. The adopters argued that it was crucial for one person or the committee to be willing to take up the subject and put effort into it.

Our findings on leadership were in line with the literature to some extent, though we did find some differences: initiators should be engaged, but it is not clear whether their trustworthiness is crucial for adoption. The board should not only be united, but also positive and engaged. Since leadership was often mentioned and often contradictory for nonadopters and adopters, we consider it to be highly influential on the outcome.

\subsection{Procedures Results}

Procedures may refer to a process being rushed (leading to nonadoption), maintenance being in line with the initiative, or decision-making in steps (leading to adoption).

Four respondents to our survey mentioned that the roofing needed to be renewed within a few years and therefore a final decision would be made after that. For now, this meant that the outcome of the process was nonadoption.

The in-depth interviews showed that-independently of the outcome-solar panels had been discussed in a previous meeting. The process took some time (1-2 years), and all initiators shared information with residents before the annual meeting. This suggests that in none of the cases was the process rushed, and stepwise decision-making took place. An important observation is that in two adopting (home) owners' associations, the roofing had been recently renewed. Another adopter 
mentioned that the roofing needed to be renewed within five years, but a practical solution was found (i.e., money was reserved for temporary replacement) so that it did not have to be a barrier for adoption. Two nonadopters mentioned that maintenance of the roof was not an issue with regard to the outcome, though in both cases the roofing was more than 15 years old. One nonadopter mentioned roofing renewal within 10 years as one of the many arguments for not adopting.

In line with the findings in the applied literature, our findings indicate that maintenance of the roof can either be a stimulus or a barrier. We did not find sufficient evidence for the other factors mentioned in the literature (a rushed process and stepwise decision-making) in terms of being an influence on the outcome.

\subsection{Information Processing Results}

Our framework postulates that information processing may refer to exemplary projects or hiring professionals, which may positively influence the outcome. Furthermore, the perception of investment may influence the outcome positively or negatively.

Our survey showed that the perception of the finances of a project may influence the outcome: 13 nonadopters stated that the payback time was perceived as long and the investment as high in comparison to other sustainable energy measures or in comparison to those implemented by neighbors. Prices were expected to drop in the future, or subsidies were considered to be needed.

The opposite seemed to hold as well: our in-depth interviews showed that the investment was perceived as a wise investment by the adopters. There were financial possibilities, and the rate of return would be higher than that from the bank. This is a puzzling result, since all projects received a report from the same consultancy, and the assumptions used for the financial calculations in the report were the same for all projects. We can only speculate, but it could be that a person's initial positive or negative disposition influenced how they looked at the figures: a positive disposition made someone more inclined to see the long-term benefits, whereas a negative disposition made someone more inclined to look at the initial investment. Alternatively, since two adopters mentioned that they had the financial means, it could be that the actual financial situation of the (home)owners' association was relevant. Our in-depth interviews further showed that all adopters considered independent advice to be very important for adoption. Both foregoing conclusions are in line with what the framework postulated.

Contrary to the findings in the literature, exemplary projects were rarely mentioned by our respondents: only once, and they were negatively related to financial calculations (see above). What was more salient in terms of explanatory value seemed to be the findings from the survey that four nonadopters contended that there were conflicts of interests: solar panels competed with rooftop terraces or the reconstruction of the top floor, or the project was in competition with other projects in terms of attention, or people did want to have solar panels but not on their own roof (as mentioned by one respondent). Our in-depth interviews confirmed that the opposite also seemed to hold: the residents provided feedback to the initiator that he had been open and honest about the potential conflict between his personal and communal interest. A possible explanation for the latter difference with the literature might be the nature of the energy measure: the literature findings were for energy-saving measures. For many of those measures (e.g., insulation, energy-efficient lighting), potential conflicts between personal and common interests are not as common. On top of this, many energy efficiency measures can fit more logically into a maintenance plan: it is quite common to save for energy-efficient lighting or to take the lifespan of double-glazing into account, since all of the buildings in our study already had these. As solar panels are often not yet present, it follows that it is not common for them to be included in a maintenance plan.

\subsection{Information Sharing Results}

Finally, our literature study revealed that adoption might be more likely if information is shared multiple times and in small portions, if it is easy to understand, and if the consequences are clear. 
Our survey did not provide strong evidence of this factor having a lot of importance, though two respondents provided indications that information on consequences could be important: one nonadopter mentioned that it was unclear who had to pay for what, and another mentioned that consequences were unclear. This was confirmed in the in-depth interviews: one adopter argued that the financial consequences for the strata fees were calculated and clear, whereas a nonadopter argued that the omission of the financial consequences might have influenced the outcome (and another nonadopter mentioned that people wanted to know in detail what the consequences were).

Our in-depth interviews showed that-regardless of the outcome-there were several moments during which communication with other residents took place: information evenings were organized, a summary of the report was sent to residents, and residents' questions were answered by e-mail or in person. Our in-depth interviews also confirmed that-regardless of the outcome- the shared information was considered clear. In our survey, however, several nonadopters mentioned the complexity of the project as a barrier. If the initiators of the project considered it complex, this might have resulted in information being shared that was not easy to understand, or even in information not being shared.

In line with the literature, we found that sharing financial consequences of the project seemed to stimulate adoption. The same held for sharing easy-to-understand information. Our empirical research did not unequivocally confirm that it is important to share information multiple times in small portions.

\section{Conclusions and Discussion}

\subsection{Conclusions}

Energy transitions have often been investigated from a systems-level perspective, and researchers have overlooked the dynamics of group decision-making processes. This paper has explored an important case, strata buildings, where these dynamics matter greatly. Whereas the potential for solar energy in cities is substantial and technical solutions are available, in a large portion of the building stock it is not the individual owner who decides. Instead, individual owners are organized in a (home) owners' association, and complex group processes precede a decision. Few studies have been done thus far on the details of these group decision processes, which is why we aimed to open up this black box. We proposed a tentative framework based on group decision-making theory and the applied literature. Our empirical confrontation showed that factors related to leadership and information processing were the most influential on the outcome, both positively and negatively.

The Netherlands is lagging behind other EU countries in achieving its energy targets. Since a large proportion of the Dutch population lives in cities, as is the case in many other industrialized countries, it is of pivotal importance that the complexity of decision-making on solar energy in collectively owned buildings is recognized. This article adds to the literature by looking more closely at the actual implementation of the energy transition, and it reveals the barriers and stimuli at the local level. Our findings may be relevant for (home) owners' associations for other aspects related to energy transitions (e.g., the transition from natural gas to other innovative forms of heating), and they may also be applicable to other voluntary initiatives related to the energy transition that involve groups (e.g., initiatives focusing on one district). Finally, our findings may be relevant for other countries in which strata buildings are part of the building stock, though then potential differences in regulations should be taken into account.

Our results revealed that some factors are more relevant than others in the context of group decision-making within (home) owners' associations. We found leadership and information processing to be the most relevant factors. The factors of groupthink, a shared mental model, and information sharing seemed to be less relevant in this context. Our results imply that it is important that one or more persons in the (home) owners' association be willing to lead and orchestrate the process. The better these leaders are, the greater the chance of a positive adoption decision. However, the group decides, 
so how information is processed by the group is just as important, if not more so. Whereas a leader may stimulate positive information processing through framing, trust, and objectivity, a positive outcome may also be fostered by the board having a clear stance, independent advice, and communication in the media. In contrast to the applied literature, we did not find sufficient evidence that the following indicators are applicable to the context of (home) owners' associations: a clear role division, trust in the strata manager, timing, stepwise decision-making, exemplary projects, or sharing information multiple times. We therefore recommend that further research on this tentative framework focus on the two factors of leadership and information processing.

\subsection{Practical Implications}

Policymakers can facilitate (home) owners' associations by responding to the factors of leadership and information processing with different policy instruments:

(a) Financial and economic incentives;

(b) Regulation and enforcement; and

(c) Education and providing information [44].

Subsidies and other economic incentives (e.g., Value Added Tax (V.A.T.) exemptions) will likely shorten the payback time and make investments more attractive to a (home) owners' association. The payback time in strata complexes is often different from that of a private homeowner because (home) owners' associations often use more energy but pay a lower price per $\mathrm{kWh}$, which prolongs the payback time. Furthermore, private homeowners can make use of a V.A.T. exemption in the purchase of solar panels, but for (home) owners' associations this is not as easily possible. This militates toward greater financial support for homeowners in strata complexes to achieve parity with private homeowners.

However, we show here that information about similar "business cases" is processed differently in different cooperatives. This suggests that it is at least as important to pay attention to what information is presented to (home)owners' associations, by whom, and how. At the very least, this shows that governments need to employ educational (as well as financial) policy instruments. The governance of renewable energy measures in (home) owners' associations is mainly voluntary, and the outcome of the process depends greatly on the voluntary efforts from a small group of residents initiating and advocating the project. To achieve a positive outcome, it is essential that the board, which works on a voluntary basis, is engaged and positive about the project. Local policymakers can therefore offer advice (information) to those willing to take up the subject and put voluntary time into it in order to facilitate a positive outcome.

Finally, the voluntary character of taking renewable energy measures as a (home) owners' association provides opportunities to employ regulation and enforcement as well. An important aspect of the Dutch situation is that procedures in (home) owners' associations require a savings of $0.5 \%$ of the total amount of money needed for reconstruction (maintenance) of the building annually. Renewable energy measures (and solar panels in particular) are not maintenance measures, but are rather improvement measures for the building. There is no legal obligation to save for improvement of the building. There is also no legal obligation to consider and apply renewable energy in strata complexes of the existing building stock. If the latter were the case, not only would this automatically engage the board in the issue, but it could also be part of the maintenance plan of the building.

\subsection{Limitations of the Study and Suggestions for Further Research}

Since the topic of our study was the decision-making process in (home)owners' associations concerning solar energy, we needed to study (home)owners' associations that voluntarily made the effort to consider the topic in the first place by asking for professional support. It should be kept in mind that we did not study a random sample of all (home) owners' associations in Amsterdam. Therefore, our study was potentially biased toward (home) owners' associations where at least a few of the residents were in favor of renewable energy measures, since they took steps to acquire 
energy advice in the first place. It would be an interesting topic of further research to study the overall willingness of (home) owners' associations to consider this topic voluntarily.

Most of the (home) owners' associations we surveyed were nonadopters This was a realistic reflection of the situation, since most of the (home) owners' associations had not yet implemented solar energy. The fact that all of the (home) owners' associations had received professional advice emphasizes that adopting solar energy generation is complex. It also implies that our results may provide more insight into the barriers in the decision-making process than into the stimuli. It would therefore be interesting to do more research on (home) owners' associations that have adopted solar energy.

Some factors found in the applied literature and in our empirical study were difficult to categorize using a decision-making framework. For example, we considered "maintenance" to be an indicator for "procedures", since decision-making about a maintenance plan is common procedure. However, roof maintenance could also be considered to fall under "strata building features", just as whether finances are available within the (home) owners' association. It would be interesting to do further research on additional strata building features that foster (or hamper) the adoption of solar panels.

Since our survey contained open questions, some respondents did mention societal factors as influencing the outcome: two nonadopters mentioned ambiguous regulations, and another two nonadopters noted that the climate had recently received much media attention, possibly creating greater awareness and a more positive attitude toward renewable energy measures in the future. For follow-up research, we recommend focusing also on the interplay between the decision-making process and societal factors.

Author Contributions: Conceptualization, methodology, formal analysis, investigation, writing-original draft preparation, and project administration: J.C.M.R. Writing-review and editing, methodology and conceptualization: D.L.T.H. and H.L.P.M. Supervision and conceptualization: P.D. All authors have read and agreed to the published version of the manuscript.

Funding: This research received no external funding.

Acknowledgments: Joy Burrough-Boenisch advised on the English of a near-final draft of the paper.

Conflicts of Interest: The authors declare no conflicts of interest.

\section{References}

1. European Parliament. Directive 2009/28/EC of the European Parliament and of the Council COUNCIL of 23 April 2009 on the Promotion of the Use of Energy from Renewable Sources. 2009. Available online: https:/eur-lex.europa.eu/eli/dir/2009/28/oj (accessed on 29 January 2019).

2. European Union. Policies, Information and Services-Cities. 2018. Available online: https://ec.europa.eu/ clima/policies/international/paris_protocol/cities_en (accessed on 4 March 2018).

3. BPD. Germany, France, The Netherlands-Housing Markets in Perspective 2016. 2016. Available online: https://www.bpdeurope.com/media/107467/q540_bpd_dunefra-2016_engels-lr-web.pdf (accessed on 21 February 2020).

4. Paulsson, J. Swedish 3D property in an International Comparison. In Proceedings of the 3rd International Workshop on 3D Cadastres: Developments and Practices, Shenzhen, China, 25-26 October 2012; Available online: https://www.fig.net/resources/proceedings/2012/2012_3dcadastre/3Dcad_2012_32.pdf (accessed on 21 February 2020).

5. Municipality of Amsterdam. Verenigingen van Eigenaren-Onderzoek, informatie en statistiek. 2018. Available online: https://www.ois.amsterdam.nl/nieuwsarchief/2018/helft-van-de-woningen-in-amsterdamonderdeel-van-vve (accessed on 5 December 2018).

6. Verbong, G.; Geels, F. The ongoing energy transition: Lessons from a socio-technical, multi-level analysis of the Dutch electricity system (1960-2004). Energy Policy 2007, 35, 1025-1037. [CrossRef]

7. Loorbach, D.; Van der Brugge, R.; Taanman, M. Governance in the energy transition: Practice of transition management in the Netherlands. Int. J. Environ. Technol. Manag. 2008, 9, 294-315. [CrossRef]

8. Kern, F.; Smith, A. Restructuring energy systems for sustainability? Energy transition policy in the Netherlands. Energy Policy 2008, 36, 4093-4103. [CrossRef] 
9. Breyer, C.; Bogdanov, D.; Gulagi, A.; Aghahosseini, A.; Barbosa, L.S.; Kosikinen, O.; Barasa, M.; Caldera, U.; Afanasyeva, S.; Child, M.; et al. On the role of photovoltaics in global energy transition. Prog. Photovolt. Res. Appl. 2017, 25, 727-745. [CrossRef]

10. Klockner, C.A.; Nayum, A. Psychological and structural facilitators and barriers to energy upgrades of the privately owned building stock. Energy 2017, 140, 1005-1017. [CrossRef]

11. Altmann, E. Apartments, Co-ownership and Sustainability: Implementation Barriers for Retrofitting the Built Environment. J. Environ. Policy Plan. 2014, 16, 437-457. [CrossRef]

12. Labanca, N.; Suerkemper, F.; Bertoldi, P.; Irrek, W.; Duplessis, B. Energy efficiency services for residential buildings: Market situation and existing potentials in the European Union. J. Clean. Prod. 2015, 109, 284-295. [CrossRef]

13. Graziano, M.; Gillingham, K. Spatial patterns of solar photovoltaic system adoption: The influence of neighbors and the built environment. J. Econ. Geogr. 2015, 15, 815-839. [CrossRef]

14. Winther, T.; Gurigard, K. Energy performance contracting (EPC): A suitable mechanism for achieving energy savings in housing cooperatives? Results from a Norwegian pilot project. Energy Effic. 2017, 10, 577-596. [CrossRef]

15. Municipality of Amsterdam. Concept RES-Het bod van deelregio Amsterdam. 2020. Available online: https://assets.amsterdam.nl/publish/pages/936557/concept_res_amsterdam.pdf (accessed on 22 February 2020).

16. Eurostat. Renewable Energy in the EU in 2018. 2020. Available online: https://ec.europa.eu/eurostat/ documents/2995521/10335438/8-23012020-AP-EN.pdf/292cf2e5-8870-4525-7ad7-188864ba0c29 (accessed on 21 February 2020).

17. CBS. Aandeel hernieuwbare energie naar 7,4 procent. 2019. Available online: https://www.cbs.nl/nl-nl/ nieuws/2019/22/aandeel-hernieuwbare-energie-naar-7-4-procent (accessed on 28 February 2020).

18. CBS. Aantallen en kenmerken van Verenigingen van Eigenaren-een verkennend onderzoek. 2016. Available online: https://www.cbs.nl/-/media/_pdf/2016/36/2016-aantallen-kenmerken-verenigingen-eigenaren.pdf (accessed on 29 January 2019).

19. Kerr, N.L.; Tindale, R.S. Group performance and decision making. Annu. Rev. Psychol. 2004, 55, $623-655$. [CrossRef]

20. Cambridge dictionary. Available online: https://dictionary.cambridge.org/dictionary/english/harmony (accessed on 8 March 2020).

21. Janis, I. Victims of Groupthink; Houghton Mifflin: Boston, MA, USA, 1972.

22. Janis, I. Groupthink: Psychological Studies of Policy Decisions and Fiascoes, 2nd ed.; Houghton Mifflin: Boston, MA, USA, 1983.

23. Manz, C.C.; Sims, H.P., Jr. The Potential for "Groupthink" in Autonomous Work Groups. Hum. Relat. 1982, 35, 773-784. [CrossRef]

24. Whyte, G. Recasting Janis's groupthink model: The key role of collective efficacy in decision fiascoes. Organ. Behav. Hum. Decis. Process. 1998, 73, 185-209. [CrossRef] [PubMed]

25. Neck, C.P.; Moorhead, G. Groupthink Remodeled: The Importance of Leadership, Time Pressure, and Methodical Decision-Making Procedures. Hum. Relat. 1995, 48, 537-557. [CrossRef]

26. Neck, C.P.; Manz, C.C. From Groupthink to Teamthink: Toward the Creation of Constructive Thought Patterns in Self-Managing Work Teams. Hum. Relat. 1994, 47, 929-952. [CrossRef]

27. Mullen, B.; Anthony, T.; Salas, E.; Driskell, J.E. Group cohesiveness and quality of decision making. Small Group Res. 1994, 25, 189-204. [CrossRef]

28. Forsyth, D.R. Group Dynamics, 5th ed.; Cengage Learning: Belmont, CA, USA; Wadsworth, OH, USA, 2006; pp. 317-349.

29. Hauge, A.L.; Thomsen, J.; Lofstrom, E. How to get residents/owners in housing cooperatives to agree on sustainable renovation. Energy Effic. 2013, 6, 315-328. [CrossRef]

30. De Vreede, T.; Reiter-Palmon, R.; De Vreede, G. The Effect of Shared Mental Models on Consensus. In Proceedings of the 2013 46th Hawaii International Conference on System Sciences, Wailea, HI, USA, 7-10 January 2013; pp. 263-272.

31. Tindale, R.S.; Smith, C.M.; Thomas, L.S.; Filkins, J.; Sheffey, S. Shared representations and asymmetric social influence processes in small groups. In Understanding Group Behavior: Consensual Action by Small Groups; Witte, E., David, J.H., Eds.; Erlbaum: Mahwah, NJ, USA, 1996; Volume 1, pp. 81-103. 
32. Mathieu, J.E.; Heffner, T.S.; Goodwin, G.F.; Salas, E.; Cannon-Bowers, J.A. The influence of shared mental models on team process and performance. J. Appl. Psychol. 2000, 85, 273-283. [CrossRef]

33. Kaufman, A. Leadership and Governance. Acad. Med. 1998, 73, S11-S15. [CrossRef]

34. Peterson, R.S.; Owen, P.D.; Tetlock, P.E.; Fan, E.T.; Martorana, P. Group dynamics in top management teams: Groupthink, vigilance, and alternative models of organizational failure and success. Organ. Behav. Hum. Decis. Process. 1998, 73, 272-305. [CrossRef]

35. Larson, J.R.; Christensen, C.; Abbott, A.S.; Franz, T.M. Diagnosing groups: Charting the flow of information in medical decision-making teams. J. Personal. Soc. Psychol. 1996, 71, 315-330. [CrossRef]

36. Davis, J.H.; Stasson, M.F.; Parks, C.D.; Hulbert, L.; Kameda, T.; Zimmerman, S.K.; Ono, K. Quantitative decisions by groups and individuals: Voting procedures and monetary awards by mock civil juries. J. Exp. Soc. Psychol. 1993, 29, 326-346. [CrossRef]

37. Kameda, T. Procedural influence in small-group decision making: Deliberation style and assigned decision rule. J. Personal. Soc. Psychol. 1991, 61, 245-256. [CrossRef]

38. Hauge, A.L.; Lofstrom, E.; Mellegard, S. How to maximize the chances of sustainable renovation in housing cooperatives. Renewable Energy Research Conference. Energy Procedia 2014, 58, 193-198. [CrossRef]

39. Stasser, G.; Titus, W. Pooling of unshared information in group decision making: Biased information sampling during discussion. J. Personal. Soc. Psychol. 1985, 48, 1467-1478. [CrossRef]

40. Kameda, T.; Takezawa, M.; Tindale, R.S.; Smith, C.M. Social sharing and risk reduction: Exploring a computational algorithm for the psychology of windfall gains. Evol. Hum. Behav. 2002, 23, 11-33. [CrossRef]

41. Wittenbaum, G.M.; Hubbel, A.P.; Zuckerman, C. Mutual enhancement: Toward an understanding of collective preference for shared information. J. Personal. Soc. Psychol. 1999, 77, 967-978. [CrossRef]

42. Brodbeck, F.C.; Kerschreiter, R.; Mojzisch, A.; Frey, D.; Schultz-Hardt, S. The dissemination of critical, unshared information in decisionmaking groups: The effects of prediscussion dissent. Eur. J. Soc. Psychol. 2002, 32, 35-56. [CrossRef]

43. Verschuren, P.; Doorewaard, H. Designing a Research Project; Eleven International Publishing: The Hague, The Netherlands, 2010.

44. Bemelmans-Videc, M.L.; Rist, R.C.; Vedung, E.O. (Eds.) Carrots, Sticks, and Sermons: Policy Instruments and Their Evaluation; Transaction Publishers: London, UK, 2011; Volume 1. 